\title{
Debatt
}

\section{Praktiknära forskning i samverkan - hur ska det gå till?}

Karin Hermansson

FoU-ansvarig Ifous

Kontakt: karin.hermansson@ifous.se

Marie-Hélène Ahnborg

VD Ifous

Kontakt: marie-helene.ahnborg@ifous.se

Vilka förväntningar är rimliga att ställa på praktiknära forskning, frågar Serder och Malmström i sin artikel i PfS tidigare i år (Serder \& Malmström, 2020). Vilka spänningar finns mellan olika parters syn och vad leder de till? Det är frågor som vi som företrädare för det fristående forskningsinstitutet Ifous (Innovation, forskning och utveckling i skola och förskola) gärna tar vidare till samverkan som en förutsättning för praktiknära forskning. Vad menar vi när vi talar om samverkan, och varför är samverkan så svårt?

I universitetens och högskolornas uppdrag ingår, förutom att erbjuda utbildning och bedriva forskning, att samverka med det omgivande samhället ${ }^{1}$. Samverkansuppdraget har tre huvudsyften: att informera om forskning, att rekrytera till utbildning och forskning och att bidra till att forskning kommer till nytta för samhället.

Många associerar samverkansuppdraget främst med forskningsförmedling, medan få utanför högskolan tänker på rekrytering. Nyttiggörandet, som för oss är det centrala, associeras inte heller alltid till samverkansuppdraget. Det kan dessutom vara kontroversiellt och uppfattas som ett hot mot forskningens frihet. Behovet av dialog är alltså stort.

Nyttiggörande innebär olika saker i olika discipliner och branscher. Medan det inom medicin, naturvetenskap och teknik ofta handlar om att omsätta forskningsresultat i produkter som kan generera nytta i form av patent, 
företagsintäkter, jobb och tillväxt är det mer abstrakt inom humaniora och samhällsvetenskap. Möjligen kan kunskapsförmedling genom forskares böcker och föreläsningar generera en liten ekonomisk vinst, men praktiknära forskningssamverkan kostar både pengar och tid.

När nyttan inte kan räknas i pengar blir inte incitamenten att samverka lika tydliga. Inom utbildningsområdet finns dock skollagen som föreskriver att utbildningen ska vila på vetenskaplig grund och beprövad erfarenhet ${ }^{2}$. En förutsättning för att de verksamma i skolan ska kunna leva upp till detta är någon form av relation till den vetenskapliga grunden, företrädesvis genom samverkan med forskare.

Mellan lärosäten och skolhuvudmän finns alltså en slags "incitamentsbalans". Det borde ge goda förutsättningar för samverkan. Trots det misslyckas vi. Varför?

Genom erfarenheter vi gjort genom åren kan vi identifiera flera bidragande faktorer:

\section{- Språkbarriärer}

Serder och Malmström (2020) pekar på att det inte finns någon entydig definition av "praktiknära". Det är också vår erfarenhet att praktiknära forskning kan betyda helt olika saker. Några menar att det är praktiknära att vara i skolverksamhet och studera vad praktiker gör, andra att det kräver att lärare aktivt engageras i forskningen. En annan språkbarriär uppstår när forskare - kanske för att hålla distansen (se Persson, 2020)- uttrycker sig så akademiskt att det antingen stöter bort praktikerna eller gör dem så imponerade av den vetenskapliga jargongen att de inte törs ställa kritiska frågor.

\section{- Olika drivkrafter}

Forskare meriterar sig genom publicering. En artikel kan ta år att få publicerad, och publicerbara forskningsfrågor är ofta av karaktären "vad händer här?", det vill säga man vill förstå vad ett skeende och varför det sker - oavsett hur det gick. En skolchef som går in i ett samverkansprojekt gör det därför att det finns problem som snabbt behöver åtgärdas. Hen har en politisk nämnd eller en styrelse att svara inför, och skattebetalarna kan ifrågasätta hur resurserna använts. Att kunna påvisa ett lyckat förbättringsarbete blir här mycket viktigare än att förstå vad som hände när det inte lyckades.

Skilda språkbruk och drivkrafter leder till olika förväntningar på vad samverkan ska leda till, och när. Tar man sig inte tid att reda ut begrepp, mål och ramar i förväg kommer garanterat en dag då minst en part upplever sig lurad. 
Utöver dessa "gap" mellan forskning och praktik finns på båda sidor en utbredd okunskap om den andre:

- Okunskap bland praktiker om bur forskning går till

Liksom allmänheten i stort har skolchefer, rektorer och lärare liten kunskap om hur den vetenskapliga processen går till. Förvånansvärt ofta finns en överdriven tilltro; man tror att forskaren kommer med Svaret som löser ens problem. Medvetenheten om forskarens förutsättningar och villkor är ännu lägre. Att lärosätena har olika lokala regler för exempelvis hur anställda forskare kan använda sin tid eller hur data får lagras, underlättar inte.

- Okunskap bland forskare om praktikens förutsättningar

Det finns också en stor okunskap bland forskare om hur lärares och skolledares vardag ser ut. Utöver risken att forskningen därmed inte behandlar för praktiken relevanta frågor, leder det till att praktiknära forskningsstudier planeras på ett sätt som inte fungerar i praktiken. Vi träffar forskare som inte känner till formuleringar i läroplanen ens inom det egna forskningsområdet. Andra vet inte hur det fungerar i en politiskt styrd organisation och har inte kunskap om villkoren för hållbart utvecklingsarbete.

Dessa gap är allt annat än enkla att överkomma. Det kräver uthållighet, lyhördhet, kreativitet, och inte minst mod. Man måste orka lyssna på den andra parten, våga erkänna när man inte förstår och vara beredd att lägga mycket tid på dialog. Här kan en överbryggande funktion underlätta mycket - någon som först kan ställa sig i ena ringhörnan och föra den enes talan gentemot den andre, och sedan byta ringhörna och tala för den andra parten när det behövs.

I Sverige finns över 1100 kommunala och fristående skolhuvudmän, från sådana som utgörs av en enda byskola till giganten Stockholms stad. Skillnaden i förutsättningar för forskningssamverkan är enorm, med allt vad det betyder för likvärdigheten. Även de 25 lärosätena varierar i storlek och har olika sätt att ta sig an samverkansuppdraget. I detta landskap utgör Ifous en samordnande och överbryggande funktion. Även om det är fullt möjligt för en enskild skolhuvudman att på egen hand initiera ett FoU-projekt i samverkan med ett lärosäte sker det sällan, av tids- och andra resursskäl. Många vittnar också om behovet av stöd i att formulera forskningsfrågor, hitta relevanta forskare, knyta kontakt med andra skolhuvudmän och i att 
driva ett reellt FoU-arbete. Behovet av en sådan nationell plattform finns även ur lärosätenas perspektiv, då Ifous i sin roll som koordinator avlastar forskarna som ofta inte har utrymme för de arbetsuppgifter som samverkan medför.

Just nu pågår försöksverksamhet kring praktiknära forskning, ULF-avtal inspirerat av vårdsektorns ALF-avtal, där syftet är samverkan mellan skolhuvudmän och lärosäten. Försöksverksamheten upphör 2021, då hållbara samverkansmodeller ska finnas på plats, manifesterade i ett nationellt ULFavtal.

Här kommer en beprövad infrastruktur för samverkan behövas, som inte måste riggas inför varje nytt samverkansprojekt. En sådan infrastruktur finns i Ifous. Vi ser gärna att den tas till vara när det nationella ULF-avtalet ska utformas.

\section{NOTER}

1 'I högskolornas uppgift ska det ingå att samverka med det omgivande samhället och informera om sin verksamhet samt verka för att forskningsresultat tillkomna vid högskolan kommer till nytta." (Högskolelagen, kap. 1, 2 §)

${ }^{2}$ Skollagen 2010:800, kap 1, 5\$

\section{REFERENSER}

Högskolelagen (SFS 1992:1434 i lydelse enligt SFS 2019:505, kap. 1). https://www.riksdagen.se/sv/dokument-lagar/dokument/svenskforfattningssamling/hogskolelag-19921434_sfs-1992-1434

Persson, Anders (2020). Dubbel närhet och distans behövs inom praktiknära forskning. Pedagogisk forskning i Sverige, 25(2-3), 149-152.

Serder Margareta och Malmström Martin (2020). Vad talar vi om när vi talar om praktiknära forskning? Pedagogisk forskning i Sverige, 25(1), 106-109.

Skollagen (SFS 2010:800, kap. 1, 5§). https://www.riksdagen.se/sv/dokumentlagar/dokument/svensk-forfattningssamling/skollag-2010800_sfs-2010-800 